\title{
Peningkatan Daya Saing Keripik Melalui Perajang Slice Kentang dan Desain Kemasan di Sumberejo, Ngablak, Magelang
}

\author{
Choiroel Anam ${ }^{1,2^{*}}$, Rhina Uchyani ${ }^{1,3}$, dan Emi Widiyanti ${ }^{1,4}$ \\ ${ }^{1}$ Pusat Studi Pendampingan Koperasi dan UMKM LPPM UNS; \\ ${ }^{2}$ Program Studi Ilmu Teknologi Pangan Fakultas Pertanian UNS; \\ ${ }^{3}$ Program Studi Agribisnis Fakultas Pertanian UNS; \\ ${ }^{4}$ Program Studi Penyuluhan dan Komunikasi Pertanian Fakultas Pertanian UNS \\ *Corresponding Author: choiroelanam@staff.uns.ac.id
}

\begin{abstract}
ABSTRAK
Penanganan pasca panen kentang di kawasan agropolitan Merbabu Desa Sumberejo Kabupaten Magelang diperlukan guna mengoptimalkan kuantitas maupun kualitas, sehingga menguntungkan produsen maupun konsumen. Produksi kentang yang berlimpah memiliki potensi untuk diolah menjadi keripik kentang dan menjadi icon oleh-oleh wisatawan di lereng Merbabu. Introduksi Teknologi Tepat Guna ini sebagai upaya peningkatan daya saing produk olahan kentang di daerah lereng Merbabu dengan berbagai kegiatan seperti fasilitasi peralatan produksi keripik kentang, introduksi mesin kentang stick dan slice, pelatihan pengolahan kentang untuk UKM, perbaikan desain kemasan, pengurusan legalitas usaha berupa P-IRT, dan fasilitasi timbangan. Hasil kegiatan ini mampu meningkatkan kapasitas produksi keripik kentang $17-20 \%$ per bulan. kualitas keripik kentang lebih seragam dan memperpanjang umur produk. Diversifikasi produk dihasilkan dengan usaha olahan kentang menjadi "Donat Kentang Merbabu" dan "Cake Kentang Merbabu". Secara keseluruhan peningkatan omset penjualan produk olahan kentang, meningkatnya daya saing produk dapat meningkatkan pendapatan kelompok petani kentang Agro Lestari Merbabu.
\end{abstract}

Kata kunci: daya saing, kentang, keripik, Merbabu, UKM

\section{ABSTRACT}

Potato post-harvest handling in the Merbabu agropolitan area of Sumberejo Village, Magelang Regency was needed in order to optimize both quantity and quality, so both producers and consumers were benefit. Abundant potato production was potentially being processed into potato chips and become an icon of tourist souvenirs on the Merbabu mountain slopes. The introduction of this Appropriate Technology is an effort to increase the competitiveness of processed potato products in the Merbabu slope area with various activities such as facilitation of potato chip production equipment, introduction of potato stick and slice machines, potato processing training for SMEs, improvement of packaging design, management of business legality in the form of P-IRT, and facilitation of the balance. The results of this activity were able to increase the production capacity of potato chips 17-20\% per month, to increase the quality of potato chips which is more uniform and to extend product shelflife. Product diversification was produced by processing potatoes into "Merbabu Potato Donuts" and "Merbabu Potato Cake". Overall increasing in sales turnover of processed potato products and increasing product competitiveness could increase the income of the Agro Lestari Merbabu potato farmers group.

Keywords: chips, competitiveness, Merbabu, potatoes, SME

\section{PENDAHULUAN}

Desa Sumberejo Kecamatan Ngablak Kabupaten Magelang merupakan sebuah desa yang terletak di Kawasan Agropolitan Merbabu, sekaligus merupakan salah satu sentra petani kentang. Harapan petani untuk mendapatkan keuntungan dengan berhasilnya produksi dan minimnya penyakit pada usaha pertaniannya sedikit terganggu setelah harga beberapa jenis 
komoditas hasil pertaniannya menurun seperti sawi dengan harga $\mathrm{Rp} 1.000 / \mathrm{kg}$, tomat $\mathrm{Rp}$ 4.000/kg, cabai keriting Rp 16.000/kg. Cabai rawit hanya pada kisaran $\mathrm{Rp} 35.000 / \mathrm{kg}$ sedangkan kentang yang menjadi andalan biasanya mencapai $\mathrm{Rp} 15.000 / \mathrm{kg}$ turut anjlok harganya hingga Rp 8.000/kg (Rachma, 2018). Penanganan pasca panen perlu mendapat perhatian serius, yang dimulai dari kegiatan bahan setelah panen sampai siap untuk dipasarkan atau digunakan konsumen dalam kondisi segar atau siap diolah lebih lanjut sebagai bahan industri (Pujimulyani, 2009). Proses pasca panen belum diperhatikan secara optimal oleh petani, padahal jika menerapkan hal tersebut dapat diperoleh pendapatan yang lebih besar karena tidak banyak hasil yang terbuang, sedikit bahan yang rusak, bahan tetap dalam keadaan baik, menarik (baik warna, rasa dan aroma), serta memenuhi standar perdagangan yang diharapkan konsumen individu maupun industri (Kartasapoetra, 1994).

Salah satu upaya mengatasi kentang yang tidak terserap oleh pasar adalah dengan mengolahnya menjadi berbagai makanan olahan seperti yang telah dilakukan oleh para pemuda di desa tersebut yaitu dengan mengolahnya menjadi keripik kentang dengan merk "Keripik Kentang Merbabu". Harapannya produk ini menjadi salah satu oleh-oleh khas bagi pengunjung yang berwisata di kawasan agropolitan Merbabu. Keripik Kentang Merbabu ini bekerja sama dengan kelompok petani kentang Agro Lestari Merbabu sebagai penyedia bahan baku kentang. Menurut (Rahmawati, 2008), pengembangan sumberdaya pelaku agribisnis dan agrowisata merupakan salah satu strategi prioritas bagi pengembangan kawasan agropolitan.

Rusdarti (2010) juga menegaskan pentingnya pengembangan dunia usaha khususnya industri mikro dan kecil bagi pembangunan ekonomi daerah karena dapat memberdayakan masyarakat melalui penyerapan tenaga kerja dan peluang lapangan kerja, dan daya tahan industri kecil merupakan cara terbaik untuk mengembangkan perekonomian daerah yang sehat. Namun selain potensi, selama ini Usaha Kecil Menengah (UKM) juga menghadapi beberapa kendala diantaranya adalah kurang profesional, penguasaan teknologi dan pemasaran yang lemah, serta rendahnya kualitas kewirausahaan dari para pelaku usaha. Hambatan pengembangan ekonomi desa secara umum dan khususnya UKM dikarenakan kurang fasilitas/akses permodalan, informasi, pasar, teknologi dan faktor-faktor penunjang bisnis lainnya (Anonim, 2016). Permasalahan pengembangan usaha tersebut juga dihadapi oleh UKM Keripik Kentang Merbabu. Solusi yang dapat diberikan adalah pelatihan teknik-teknik pemasaran praktis dengan tujuan agar dapat rnemperluas area pemasaran produk dan dapat mengelola pemasaran produknya dengan baik seperti gencar melakukan promosi di toko oleholeh (Riptanti dan Anam, 2016).

Keripik Kentang Merbabu merupakan sebuah usaha produktif yang memproduksi keripik kentang yang awal berdirinya diinisiasi oleh kelompok pemuda-pemuda desa yang ingin mengolah kentang yang tidak terserap pasar menjadi produk yang bernilai tinggi dan memberikan penghasilan bagi pemuda-pemuda setempat. Kelompok usaha ini telah berdiri selama 4 bulan yang lalu tepatnya di Kragon Rt 1 Rw 3 Desa Sumberejo Kecamatan Ngablak Kabupaten Magelang. Jumlah tenaga kerja yang terlibat dalam usaha ini adalah sebanyak 20 pemuda desa dan diketuai oleh Ade Rifai. Dalam melakukan usaha keripik kentang ini, ada pembagian tugas meliputi pemuda yang bertugas dalam proses penggorengan, proses packing dan pemasaran. Kapasitas produksi dari usaha ini adalah $1500 \mathrm{~kg}$ per bulan dengan harga jual Rp 5000 untuk kemasan $50 \mathrm{~g}$ dan Rp 7500 untuk kemasan 75 g. Keripik kentang Merbabu telah dipasarkan di beberapa tempat wisata di Magelang dan Yogyakarta.

Untuk mendapatkan bahan baku kentang, Kelompok Keripik Kentang Merbabu bekerja sama dengan Kelompok Petani Kentang Agro Lestari Merbabu. Kelompok petani kentang ini berdiri sejak bulan November 2016 yang diketuai oleh Agus Widodo. Jenis kentang yang ditanam oleh kelompok ini adalah kentang granola yang biasa dipergunakan oleh beberapa industri makanan seperti yang digunakan pada industri keripik komersial industri nasional dan internasional. Kapasitas produksi kelompok ini adalah 20 ton per bulan. Dari kentang yang dihasilkan mereka akan menyuplai sebesar 3 ton kentang per bulan untuk Keripik Kentang Merbabu. Namun kentang sebesar 3 ton yang diperuntukkan untuk kelompok ini tidak semuanya mampu terolah karena kelompok keripik kentang masih terbatas kemampuan produksinya karena keterbatasan peralatan produksi.

Potensi Keripik Kentang Merbabu merupakan produk yang cukup luas 
konsumennya karena hampir semua orang menyukai kentang. Namun pada kenyataannya usaha Keripik Kentang Merbabu dan kelompok tani kentang ini masih menemui beberapa kendala baik dari sisi produksi maupun pemasaran. Dari sisi produksi, permasalahannya pada keterbatasan alat produksi dan masih tradisionalnya proses pengolahan yang menyebabkan rendahnya produktivitas (kuantitas) dan kualitas produk, disamping itu kentang yang berasal dari kelompok tani juga belum tersortir sehingga menyebabkan ukuran keripik berbeda-beda. Sedangkan permasalahan pemasaran lebih pada keterbatasan modal sehingga efisiensi biaya pengemasan tidak tercapai dan belum adanya legalitas usaha yang menyebabkan kurangnya kepercayaan konsumen. Diharapkan dengan diversifikasi produk yaitu usaha olahan kentang dan memiliki legalitas usaha seperti Produk Industri Rumah Tangga (P-IRT) diharapkan dapat meningkatkan omset penjualan dan meningkatkan pendapatan petani kentang.

\section{METODE}

Kegiatan ini mengikutsertakan mitra UMKM yaitu Keripik Kentang Merbabu dan petani kentang Agro Lestari Merbabu yang berada di kawasan Agropolitan Merbabu, di Kragon Rt 1 Rw 3, Sumberejo, Ngablak, Magelang. Kegiatan Program Kemitraan Masyarakat (PKM) yang dilaksanakan meliputi penanganan pasca panen kentang berupa fasilitasi peralatan produksi, perbaikan desain kemasan, introduksi alat perajang slice kentang, pelatihan diversifikasi olahan kentang, perijinan P-IRT serta monitoring dan evaluasi kegiatan.

Kegiatan penanganan pasca panen dengan memberikan solusi dari sisi produksi dalam bentuk introduksi teknologi alat pengiris kentang semi otomatis yang dapat mengiris kentang dengan ketebalan yang seragam dan menghasilkan irisan yang jauh lebih banyak dibandingkan dengan pengirisan sebelumnya yang dilakukan secara manual. Disamping itu juga diberikan bantuan fasilitas peralatan produksi dengan tujuan meningkatkan kuantitas dan kualitas produk serta pelatihan untuk meningkatan keterampilan SDM dan dari sisi manajemen dengan pengajuan legalitas usaha dan perbaikan kemasan. Diawali dengan pelatihan pentingnya penanganan pasca panen, diversifikasi produk olahan berbasis kentang, pengenalan dan cara pembuatan berbagai olahan kentang donat kentang, kentang frozen, dan aneka cake, serta introduksi alat pengiris dan perajang kentang mulai dari pengenalan komponen dan masing-masing fungsinya, cara pengoperasian hingga perawatannya.

Untuk melihat sejauh mana tingkat keberhasilan kegiatan dilakukan kegiatan monitoring sebanyak tiga kali yaitu pertama dilaksanakan pada 2 minggu pasca kegiatan pelatihan untuk melihat hasil produksi olahan kentang donut kentang dan hasil test pasarnya. Monitoring kedua dilaksanakan 1 bulan pasca kegiatan pelatihan untuk melihat perkembangan kuantitas dan kualitas produk keripik kentang dan monitoring ketiga dilakukan 2 bulan pasca kegiatan pelatihan untuk melihat perkembangan respon pasar terhadap produk keripik premium dan produk lainnya serta melakukan pengecekan apakah terdapat kendala dalam penggunaan dan perawatan alat.

\section{HASIL DAN PEMBAHASAN}

\section{Penanganan Pasca Panen Kentang}

Kentang (Solanum tuberosum L)

merupakan salah satu bahan pangan pokok di tanah air, bahkan di beberapa negara. Berbagai variasi olahan makanan berbasis kentang oleh masyarakat banyak kita jumpai mulai dari pencampur sop, dicampur dengan sayur lain, aneka lauk seperti perkedel, kentang goreng, hingga berbagai olahan modern seperti keripik kentang, stik kentang, donat dan aneka cake berbahan dasar kentang (Kartasapoetra, 1994). Pemanenan kentang akan lebih baik jika pada cuaca cerah, kemudian dibiarkan beberapa jam dibawah sinar matahari, supaya mudah dalam pembersihan tanah kering yang menempel pada umbi kentang. Pembersihan umbi dari tanah dilakukan dengan mengusap menggunakan tangan, sekaligus berfungsi untuk sortasi antara umbi kentang yang besar, mulus dipisahkan dengan yang sedang dan yang kecil mulus. Kentang yang rusak atau cacat tetapi tidak busuk dapat dipisahkan dan digunakan sebagai bahan pembuatan kering kentang goreng. Kentang yang tidak segera dipasarkan dapat disimpan pada ruang yang dilengkapi dengan sistem aerasi yang cukup. Jika memungkinkan dengan pengaturan temperatur dan kelembapan ruangan. Selama dua minggu pertama temperatur gudang sekitar $60-70{ }^{0} \mathrm{~F}$ dengan kelembapan sekitar $90 \%$. Guna mencegah tumbuhnya tunas pada kentang dalam penyimpanan yang lama, misalnya lebih dari 2 bulan, maka dapat 
dilakukan pengaturan temperatur pada suhu 34 ${ }^{0} \mathrm{~F}$ secara tetap sampai dua minggu sebelum pemasaran. Penempatan kentang tidak secara bertumpukan serta pembalikan letak umbi pada waktu tertentu sangat direkomendasikan.

Memilih kentang yang baik tentu dapat dilihat dari umbinya yang keras, permukaannya rata, kulitnya mulus, tidak bernoda, dan tidak terdapat tunas. Disarankan tidak memilih kentang yang terdapat bercak hijau sebab merupakan indikasi adanya solanin (racun) yang menyebabkan rasa pahit dan dapat bereaksi dalam saluran pencernaan.

\section{Fasilitasi Peralatan Produksi}

Penambahan fasilitasi peralatan produksi dilakukan untuk mengatasi permasalahan terbatasnya peralatan produksi yang menyebabkan terbatasnya produksi. Peralatan produksi yang diberikan (Gambar 1) meliputi: sebuah kompor 1 tungku, tabung elpiji dan regulator, seperangkat alat pemasak berupa sebuah wajan dengan diameter $36 \mathrm{~cm}, 4$ buah baskom plastik dan stainless ukuran $20 \mathrm{~cm}$, timbangan dapur digital merek camri, wakul saringan 2 buah, kursi pendek 2 buah dan kursi plastik tinggi kerja 4 buah, sebuah mixer Philip untuk pembuatan adonan donat kentang, serta container box 2 buah. Berikut gambaran penyerahan peralatan produksi yang diserahkan kepada perwakilan kelompok pemuda-pemuda di Desa Sumberejo. Bantuan peralatan produksi ini diberikan karena selama ini proses produksi menggunakan peralatan rumah tangga yang digunakan untuk memasak setiap harinya. Tersedianya peralatan produksi secara khusus, tentu membuat kelancaran proses produksi dapat berjalan lancar, karena tidak mengganggu rumah tangga yang digunakan sebagai tempat produksi. Demikian juga anggota kelompok yang akan melaksanakan produksi dapat melakukan setiap waktu, kualitas produk juga lebih terjamin dengan penggunaan alat yang tidak tercampur dengan produk lain.
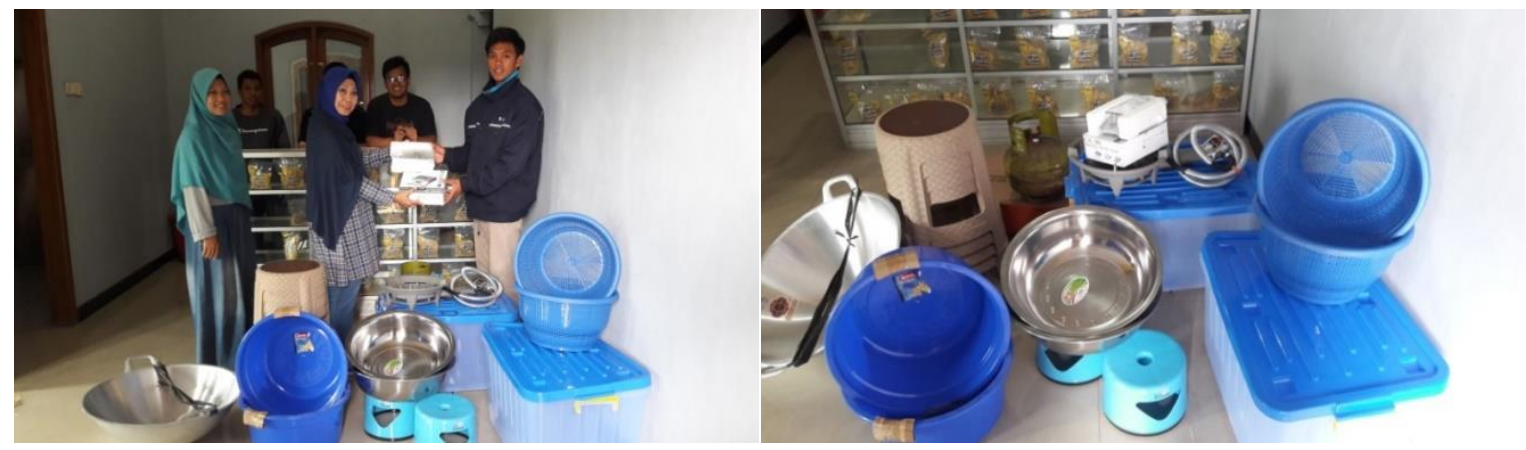

Gambar 1. Penyerahan peralatan produksi pada UKM keripik kentang

\section{Desain Kemasan}

Kemasan memegang peran penting dalam sebuah produk, termasuk produk makanan dan minuman. Fungsi utama kemasan yaitu mewadahi dan melindungi produk dari bahaya biologis, kimia dan fisik produk yang dikemas mulai dari proses produksi hingga distribusi. Fungsi lain kemasan adalah lebih memudahkan konsumen mengenali suatu produk, karena pada kemasan akan tercantum identitas produk seperti nama produk, komposisi bahan yang digunakan, alamat produsen, tanggal produksi hingga waktu produk tersebut boleh digunakan. Hal ini dapat meningkatkan daya tarik konsumen dan pada akhirnya dapat meningkatkan nilai jualnya.

Hasil Program Kemitraan Masyarakat dengan mitra Kelompok Keripik Merbabu, diharapkan dapat memperluas akses pasar. Karena pemasaran merupakan salah satu kunci keberhasilan dan kelancaran usaha. Berhasil tidaknya pencapaian tujuan usaha tergantung pada keahlian orang-orang dalam bidang pemasaran, produksi, dan keuangan. Tampilan produk keripik untuk pasar reguler dikemas dengan kemasan plastik transparan, sedangkan segmen kelas premium dengan tampilan kemasan tertutup yang lebih exclusive model standing pouch kraft dilengkapi tutup reseal. Untuk kemasan exclusive akan digunakan brand Pikebu (Keripik Kentang Merbabu) demikian juga untuk kemasan regular masih dengan brand lama. Pada kegiatan ini telah dilakukan perbaikan kemasan pada kemasan keripik kentang yang terlihat pada Gambar 2.

Diversifikasi produk kentang yang direncanakan berikutnya adalah donut kentang dengan menggunakan brand Dokebu (Donat Kentang Merbabu). Donat merupakan produk 
makanan yang mulai banyak disukai masyarakat Indonesia. Hal ini terlihat dari semakin banyaknya gerai donat maupun toko di berbagai pelosok kota maupun desa. Varian donat di pasaran yang semakin beragam menambah bukti perkembangan donat yang baik, khususnya terkait dengan pemanfaatan pangan lokal pada produk donat. Salah satu produk pangan lokal yang digunakan yaitu kentang (Wahyuningtyas dan Bahar, 2018). Di Indonesia sudah banyak masyarakat menggunakan kentang sebagai bahan dalam pembuatan donat. Tekstur donat kentang lembut dan empuk sehingga menjadi pilihan konsumen. Kentang mengandung karbohidrat, protein, mineral, ditambah vitamin C dan B1 (Samadi, 2007).

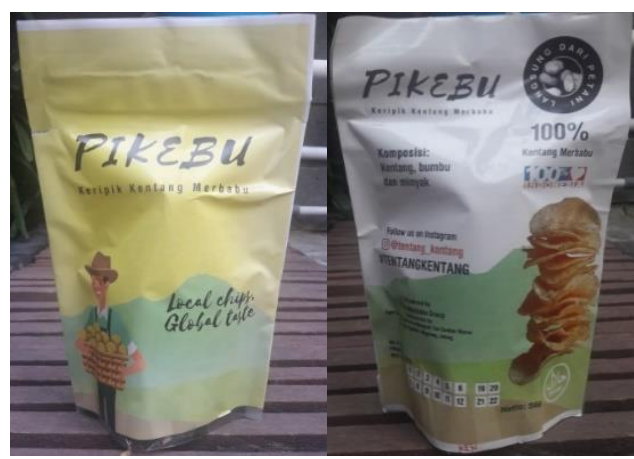

Gambar 2. Perbaikan kemasan keripik kentang "Pikebu"

\section{Introduksi Alat Perajang Slice Kentang}

Proses pemotongan atau mengiris hasil pertanian seperti umbi umbian jika jumlahnya kecil dapat dikakukan secara manual menggunakan pisau atau alat pemotong lain. Namun jika jumlahnya cukup besar, seperti pada pembuatan keripik ataupun gaplek, pengirisan cara manual perlu waktu dan tenaga kerja cukup besar. Untuk mengatasi permasalahan tersebut diperlukan mesin pemotong atau mesin pengiris semi otomatis yang berkapasitas lebih tinggi (Pangihutan et al., 2016). Tujuannya adalah pengiris dan pemotong mengecilkan ukuran bahan, memperpendek waktu penyiapan bahan untuk proses penanganan selanjutnya.

Introduksi alat perajang kentang ditujukan untuk meningkatkan daya saing produk. Karena dengan alat pemotong, potongan kentang yang dihasilkan ketebalannya seragam, cepat dalam pemotongan dan bentuk kentang yang lebih baik dan utuh. Pada awal pengajuan kegiatan, alat yang diajukan hanya berskala rumah tangga, namun seiring kebutuhan mitra maka alat perajang yang diberikan berkapasitas lebih besar dengan sumber energi listrik. Spesifikasi mesin perajang slice sebagai berikut:

- Energi yang digunakan : Listrik

- Spek mesin : 1/4 HP; 220 Volt; $50 \mathrm{~Hz} ; 2,36$ A; 1400 RPM

- Kapasitas pemrosesan : $100 \mathrm{~kg} / \mathrm{jam}$

- Dimensi panjang x lebar : 70 x $40 \mathrm{~cm}$

- Ukuran output dapat diatur secara manual

Kegunaan dari alat perajang ini adalah untuk memotong kentang sehingga berbentuk lembaran tipis dengan ketebalan yang seragam untuk keripik ketebalannya $2 \mathrm{~mm}$. Adapun manfaat yang dirasakan oleh UKM adalah mempercepat pekerjaan, menghemat waktu dan tenaga (efisiensi proses produksi), meningkatkan daya saing produk. Gambaran alat perajang kentang yang diintroduksikan seperti Gambar 3.

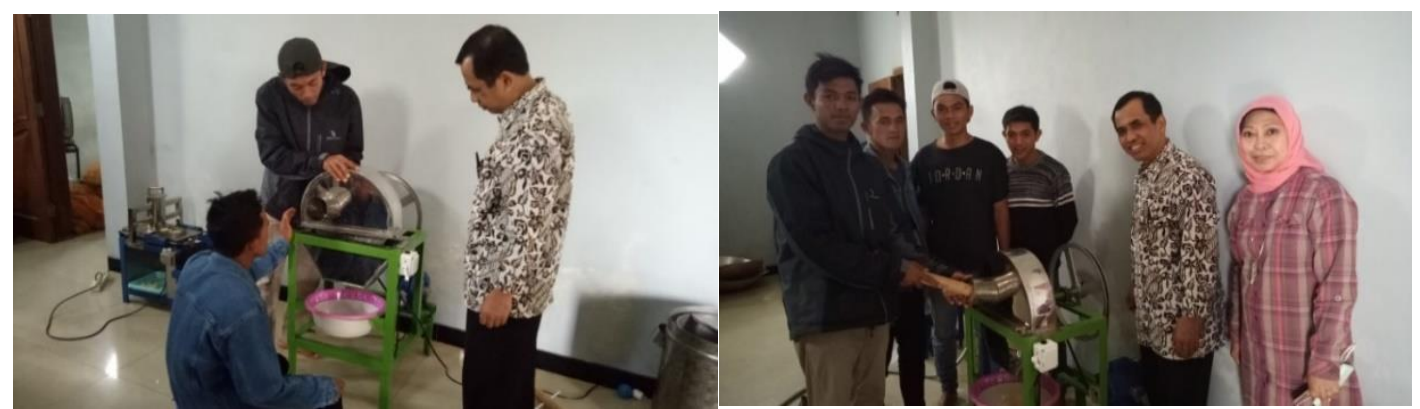

Gambar 3. Alat Perajang keripik kentang

Proses pengirisan diawali dengan mengatur pisau pengiris untuk menetukan ketebalan irisan yang diinginkan biasanya $2 \mathrm{~mm}$ dan memastikan baut pengunci sudah terpasang dengan kuat. Kemudian menghubungkan aliran listrik guna menghidupkan motor listrik sebagai penggerak pisau, dilanjutkan kentang yang akan diiris dimasukkan ke dalam lubang atau hoper. Kentang didorong menggunakan kayu yang sudah didesain khusus ke arah pisau, sambil 
menghidupkan saklar listrik yang menggerakkan piringan berisi pisau secara memutar dan memotong umbi dengan ketebalan yang seragam. Begitu seterusnya jika kentang dalam hoper habis terus diisi sampai kentang yang sudah dikupas habis. Hasil kentang yang sudah terpotong ditampung pada bagian bawah pisau dengan menggunakan baskom, dan siap untuk ditambahkan bumbu serta digoreng. Proses perajangan dengan slicer kentang telah menghemat waktu dan tenaga. Sebelumnya untuk mengiris $100 \mathrm{~kg}$ kentang diperlukan waktu 4 jam dengan 3 orang perajang. Kapasitas slicer kentang ini $100 \mathrm{~kg}$ per jam. Namun belum dimanfaatkan secara optimal, karena akses pemasaran produk kripik kentang masih terbatas pada daerah wisata Kopeng, Magelang dan sekitarnya.

Berdasarkan monitoring yang dilakukan, setelah menggunakan alat perajang slicer kentang, terdapat peningkatan hasil pemasaran $77-80 \%$ atau setiap bulan kentang yang dirajang 1750-1800 kg. Hal ini antara lain disebabkan ketebalan irisan kentang yang seragam, penampakan yang lebih menarik, dan kualitas kripik kentang yang lebih baik. Seperti permasalahan pada UKM lainnya setelah berhasil meningkatkan kualitas dan kuantitas produknya, persoalan berikutnya adalah bagaimana dapat memasarkan produksinya. Oleh karena itu UKM juga diberikan strategi akses perluasan pasar mulai dari kerjasama dengan pusat oleh-oleh, hingga penjualan secara online. Disamping itu juga dilakukan pelatihan diversifikasi produk olahan kentang supaya konsumen mendapatkan beberapa alternatif jajanan sebagai buah tangan.

\section{Pelatihan Diversifikasi Olahan Kentang}

Pelatihan olahan kentang dilakukan selama 2 hari yaitu tanggal 16-17 Agustus 2019 dengan peserta sejumlah 25 orang yang terdiri dari para pemuda anggota Karang Taruna di desa Sumberejo. Pada hari pertama diberikan materi tentang 1) proses pengolahan produk kentang seperti donat, kentang goreng, dan keripik kentang, 2) pengemasan produk dan 3) potensi pasar dan strategi pemasaran olahan kentang. Pada hari kedua difasilitasi praktek langsung pembuatan produk. Peserta diajak langsung untuk melakukan proses produksi dan diberikan tutorial atau pendampingan mulai dari pengupasan, perendaman, penggunaan mesin pengiris/slice kentang, penggunaan spinner sampai dengan pengemasan.

Peserta sangat antusias dan memberikan respon positif terhadap materi yang diberikan ditandai dengan adanya pertanyaan dan ketertarikan dalam pembuatan produk dan penggunaan teknologi dalam produksi selama proses pelatihan. Berikut gambaran pelaksanaan pelatihan diversifikasi olahan kentang yang diikuti oleh pemuda-pemudi di Desa Sumberejo Kecamatan Ngablak Kabupaten Magelang (Gambar. 4).

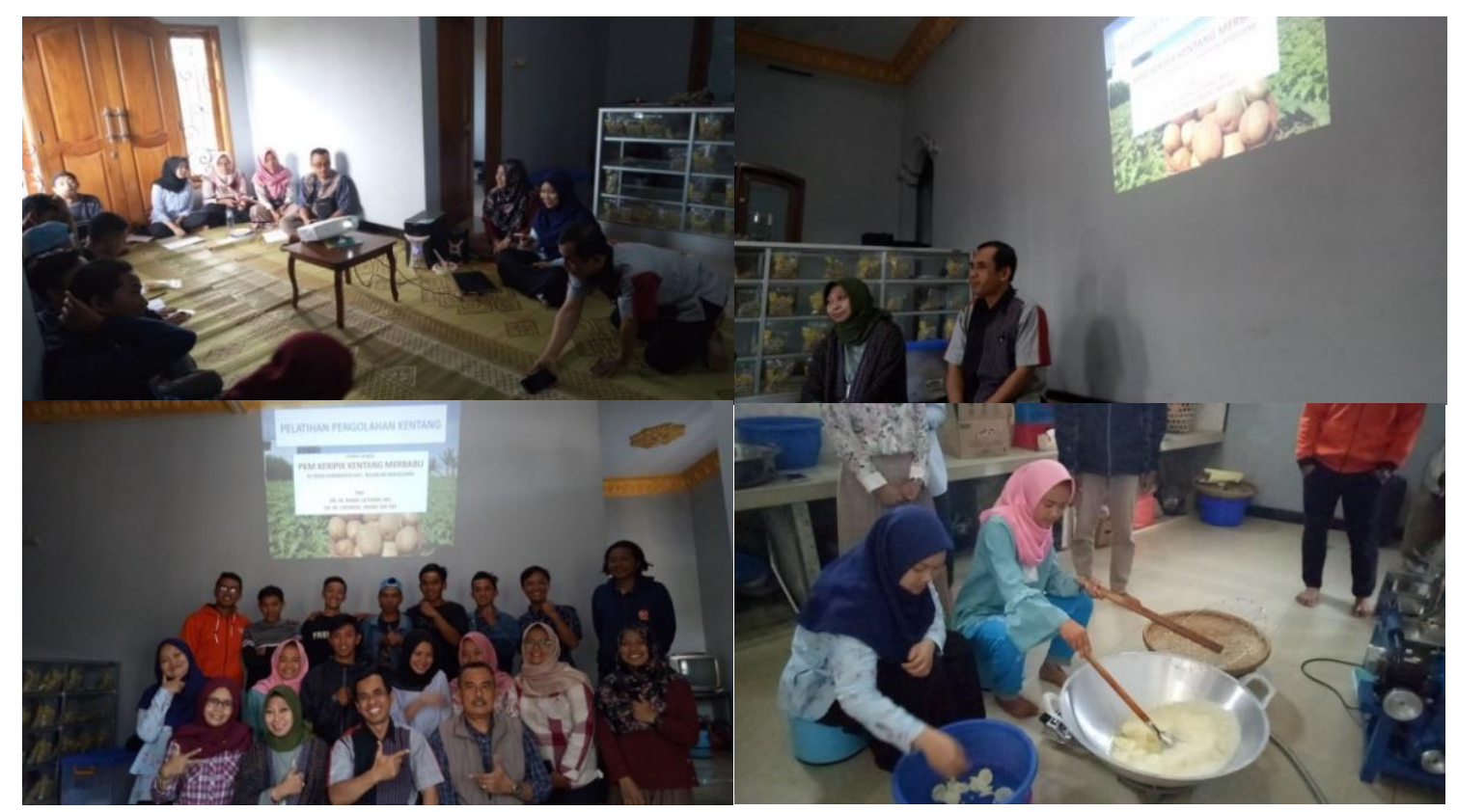

Gambar 4. Pelatihan diversifikasi olahan kentang 


\section{Perijinan P-IRT}

Keripik kentang merupakan salah satu makanan yang mendapatkan pengawasan dalam pemasaran dari pihak berwenang atau pemerintahan. Produk yang beredar di masyarakat tidak dapat secara sembarangan dijual kepada konsumen tanpa adanya izin yang menjelaskan bahwa makanan tersebut aman untuk dikonsumsi masyarakat. Demikian juga bagi pembeli, tentu perlu lebih selektif memilih mana makanan yang layak untuk dikonsumsi. Sertifikat P-IRT atau Pangan Industri Rumah Tangga merupakan sertifikat yang dikeluarkan oleh Dinas Kesehatan kabupaten atau kota bagi produk makanan yang dihasilkan oleh usaha kecil yang akan dipasarkan dan sudah melalui beberapa tahapan uji sehingga produk tersebut dinyatakan benar benar aman dikonsumsi.

Produsen makanan yang mengajukan $\mathrm{P}$ IRT akan diberikan materi penyuluhan bagaimana cara produksi pangan olahan yang baik, mulai dari memilih bahan baku, cara produksi yang benar, sampai cara mengatasi kemungkinan gangguan kontaminasi pada pangan. Setelah disampaikan penyuluhan petugas akan survei secara langsung ke lokasi usaha sekaligus mengambil sampel produk untuk uji laboratorium makanan yang didaftarkan. Hal ini berfungsi untuk memastikan tempat produksi benar-benar layak digunakan. Sampai dengan disusunnya tulisan ini proses perijinan P-IRT sampai pada tahap pengambilan menunggu visitasi lapang dan dari segi kondisi produksi dan tempat usaha UKM ini layak mendapatkan sertifikat P-IRT.

\section{KESIMPULAN}

Kegiatan Progrm Kemitraan Masyarakat ini telah berjalan sangat baik, dengan berhasilnya desain dan penerapan alat pengiris kentang yang merupakan tahapan pokok dalam produksi keripik kentang, sehingga hasil irisan kentang dapat seragam, cepat dan bersih. Dengan adanya alat pengiris kentang dapat meningkatkan kapasitas produksi dari $1000 \mathrm{~kg}$ menjadi $1750-1800 \mathrm{~kg}$ kentang per bulan atau meningkat $75 \%$ sampai dengan $80 \%$ per bulan. Desain kemasan untuk berbagai produk olahan berbahan baku kentang juga sudah disepakati dengan UKM. Saat ini UKM sedang menunggu ijin P-IRT dari Dinas Kesehatan setempat untuk dicantumkan pada kemasan produknya. Keberlangsungan kegiatan ini sangat baik karena melibatkan pemuda dan karang taruna sebagai penggerak sekaligus terus melakukan peluang akses pemasaran di daerah wisata Kopeng, Magelang, Salatiga dan sekitarnya.

\section{UCAPAN TERMA KASIH}

Penulis menyampaikan terima kasih kepada UNS melalui Program Kemitraan Masyarakat, dengan dana PNBP tahun Anggaran 2019 dengan surat perjanjian Nomor: 517/UN27.21/PM/2019.

\section{DAFTAR PUSTAKA}

Anonim. (2016). Ada Sebanyak 56 Juta Usaha Kecil Menengah (UKM) di Indonesia dan $70 \%$ diantarnya Terdiri dari UKM Pangan. UKM Terbukti Memiliki Kemampuan dan Potensi Menjadi Penggerak Ekonomi. Retrieved from http://presidenri.go.id/berita-aktual/poten si-besar-ukm-industri-makanan-minuman .html

Kartasapoetra, A. G. (1994). Teknologi Penanganan Pasca Panen (Edisi 1). Jakarta: Rineka Cipta.

Pangihutan, S., Rohanah, A., \& Daulay, S. B. (2016). Rancang Bangun Alat Pengiris Kentang Screw Mekanis. Jurnal Rekayasa Pangan dan Pertanian, 4(3), 403-108. Retrieved from https://docplayer.info/48 149814-Rancang-bangun-alat-pengiris-ke ntang-screw-mekanis.html

Pujimulyani, D. (2009). Teknologi Pengolahan Sayur-Sayuran dan Buah-Buahan. Yogyakarta: Graha Ilmu. Retrieved from http://grahailmu.co.id/previewpdf/978-97 9-756-475-9-496.pdf

Rachma, F. (2018). Berita Magelang - Panen Raya, Petani Gunung Andong Alami Paceklik. Retrieved June 3, 2020, from http://beritamagelang.id/panen-raya-peta ni-gunung-andong-paceklik

Rahmawati, N. F. (2008). Pengaruh Pelaksanaan Agropolitan terhadap Perkembangan Ekonomi di Tujuh Kawasan Agropolitan Kabupaten Magelang. Program Studi Ekonomi Pertanian dan Sumberdaya Fakultas Pertanian, Institut Pertanian Bogor. Retrieved from https://repository.ipb.ac.id/jspui/bitstream /123456789/2515/1/A08nfr_abstract.pdf

Riptanti, E. W., \& Anam, C. (2016). Peningkatan Kualitas dan Diversifikasi 
Produk Olahan Ikan Lele. E-Dimas: Jurnal Pengabdian Kepada Masyarakat, 7(2), 38. https://doi.org/10.26877/e-dimas .v7i2.1131

Rusdarti, R. (2010). Potensi Ekonomi Daerah dalam Pengembangan UKM Unggulan di Kabupaten Semarang. JEJAK: Jurnal Ekonomi dan Kebijakan, 3(2), 143-155. https://doi.org/10.15294/jejak.v3i2.4657

Samadi, B. (2007). Kentang dan Analisis Usaha Tani (Cetakan 1). Yogyakarta: Kanisius.
Retrieved from https://books.google.co.id /books?id=vz-MHRTIQqwC

Wahyuningtyas, T. A., \& Bahar, A. (2018). Pengaruh Proporsi Kentang, Puree Ubi Jalar Putih (Ipomoea batatas) dan PUREE Wortel (Daucus carota L.) terhadap Sifat Organolpetik Donat. Jurnal Tata Boga, 7(1), 116-125. Retrieved from http:// jurnalmahasiswa.unesa.ac.id/index.php/ju rnal-tata-boga/article/view/22981 